\title{
STUDIES IN DIPLOMACY
}

General Editor: G. R. Berridge, Director, Centre for the Study of Diplomacy, University of Leicester

The series was launched in 1994. Its chief purpose is to encourage original scholarship on the theory and practice of international diplomacy, including its legal regulation. The interests of the series thus embrace such diplomatic functions as signalling, negotiation and consular work, and methods such as summitry and the multilateral conference. Whilst it has sharp focus on diplomacy at the expense of foreign policy, therefore, the series has no prejudice as to historical period or approach. It also aims to include manuals on protocol and other aspects of diplomatic practice which will be of immediate, day-to-day relevance to professional diplomats. A final ambition is to reprint inaccessible classic works on diplomacy.

Titles include:

Andrew F. Cooper (editor)

NICHE DIPLOMACY

Middle Powers after the Cold War

David H. Dunn (editor)

DIPLOMACY AT THE HIGHEST LEVEL

The Evolution of International Summitry

Brian Hocking (editor)

FOREIGN MINISTRIES

Change and Adaptation

Donna Lee

MIDDLE POWERS AND COMMERCIAL DIPLOMACY

British Influence at the Kennedy Trade Round

Jan Melissen (editor)

INNOVATION IN DIPLOMATIC PRACTICE 
M. J. Peterson

RECOGNITION OF GOVERNMENTS

Legal Doctrine and State Practice, 1815-1995

Gary D. Rawnsley

RADIO DIPLOMACY AND PROPAGANDA

The BBC and VOA in International Politics, 1956-64

Studies in Diplomacy

Series Standing Order ISBN 978-0-333-71495-9

(outside North America only)

You can receive future titles in this series as they are published by placing a standing order. Please contact your bookseller or, in case of difficulty, write to us at the address below with your name and address, the title of the series and the ISBN quoted above.

Customer Services Department, Macmillan Distribution Ltd Houndmills, Basingstoke, Hampshire RG21 6XS, England 


\section{Middle Powers and Commercial Diplomacy}

\section{British Influence at the Kennedy Trade Round}

Donna Lee

Lecturer in Politics

University of Leicester 


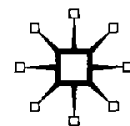

(C) Donna Lee 1999

Softcover reprint of the hardcover 1st edition 1999 978-0-333-73984-6

All rights reserved. No reproduction, copy or transmission of this publication may be made without written permission.

No paragraph of this publication may be reproduced, copied or transmitted save with written permission or in accordance with the provisions of the Copyright, Designs and Patents Act 1988, or under the terms of any licence permitting limited copying issued by the Copyright Licensing Agency, 90 Tottenham Court Road, London W1T 4LP.

Any person who does any unauthorised act in relation to this publication may be liable to criminal prosecution and civil claims for damages.

The author has asserted her right to be identified as the author of this work in accordance with the Copyright, Designs and Patents Act 1988.

Published by

PALGRAVE MACMILLAN

Houndmills, Basingstoke, Hampshire RG21 6XS and

175 Fifth Avenue, New York, N. Y. 10010

Companies and representatives throughout the world

PALGRAVE MACMILLAN is the global academic imprint of the Palgrave Macmillan division of St. Martin's Press, LLC and of Palgrave Macmillan Ltd. Macmillan ${ }^{\circledR}$ is a registered trademark in the United States, United Kingdom and other countries. Palgrave is a registered trademark in the European Union and other countries.

Outside North America

ISBN 978-1-349-40948-8

ISBN 978-0-333-98435-2 (eBook)

DOI $10.1057 / 9780333984352$

Inside North America

ISBN 978-0-312-22044-0

This book is printed on paper suitable for recycling and made from fully managed and sustained forest sources.

A catalogue record for this book is available from the British Library.

Library of Congress Catalog Card Number: 98-49904 
For Grandma Knowles 



\section{Contents}

Preface

List of Abbreviations xiii

Introduction $\quad 1$

1 Middle Power Influence in the International System 13

2 Background to the Kennedy Round 29

3 The Formative Stage, 1962-64 56

4 Non-Grains Agriculture, 1964-66 72

5 The IGA and Industrial Tariffs, 1964-66 95

6 The Final Stage, $1967 \quad 109$

Conclusion 138

$\begin{array}{ll}\text { Glossary } & 148\end{array}$

$\begin{array}{ll}\text { Bibliography } & 149\end{array}$

$\begin{array}{ll}\text { Index } & 156\end{array}$ 



\section{Preface}

Generally, too few political scientists make use of historical materials in their theory-building efforts. International relations scholars are particularly guilty of grand theorizing on the basis of narrow, secondary sources. In the area of foreign policy analysis Deighton complains that 'Much of what is written about conceptual, strategic and foreign policy issues is based on secondary sources, even for periods for which archival evidence is available.' International relations theory can only benefit from a larger empirical base for its theory building. American scholars have dominated this field, and their scientific approach seldom incorporates the historical emphasis inherent in the British literature. John Lewis Gaddis rightly points out that 'political scientists who generalize but do not use archives are missing an important opportunity.'2

Existing accounts of the Kennedy Round have missed just such an opportunity. They are either based on personal experience of American officials or on secondary material, and written almost exclusively from an American perspective. They suffer from focusing exclusively on US-European Economic Community (EEC) ${ }^{3}$ dialogues; little mention is made of other participants. This narrow focus, while understandable at the time of writing - when most official records were secretly filed away in government departments needs re-examination. Recently opened British and American government documents provide a broader perspective on the Kennedy Round negotiations. These documents reveal an active and creative British role that has been entirely missed.

In 1995 the British Department of Trade and Industry gave me access to previously closed Board of Trade documents at the Public Record Office in Kew. I also studied recently opened material of the Board of Trade, Foreign Office and Treasury departments. These extensive files include all written documentation received and produced by the Board of Trade during the Kennedy Round negotiations and include reports of the state of the negotiations, telegrams flowing between Geneva and London, memos of interdepartmental meetings between Board of Trade officials and the British delegation to Geneva, and memos of similar meetings with other departments such as the Foreign Office and Treasury as well as the Cabinet. More interestingly, they include records of the many bilateral meetings with 
Community and American officials. These were both formal and informal, taking place in government offices, embassies and restaurants in the various capitals.

In the United States, I researched the archival material at the Lyndon B. Johnson Library, the John F. Kennedy Library, and the Dean Acheson collection at the Sterling Memorial Library at Yale University. I also reviewed the Dean Acheson Papers at the Truman Library which were passed on to me by Professor John Young of Leicester University. At the two Presidential libraries some of the documents on the Kennedy Round and Anglo-American relations were made available as recently as $1995 .{ }^{4}$ In both libraries I found that a large amount of the material was either closed or sanitized. Extensive classification of Presidential documents proved to be especially problematic at the JFK library where so much material remains closed. Beginning my research, I had assumed that American documents would be more open to research than British, but my experience shows this to be wrong. It would appear that the 1992 Waldegrave Initiative has indeed generated a more liberal attitude on the part of departmental records officers to declassification. ${ }^{5}$ Though less extensive and more sanitized than the British documents, the American documents also show extensive bilateral meetings between politicians and officials of every level of the various participating countries. Similar to the British documents there are reports, memos, cables, notes, letters - a plethora of communications between American officials, and between American officials and their counterparts from other participating countries.

The research for this book was made possible by a Moody Grant from the LBJ Foundation, and research awards from the Research Foundation, University of Connecticut, and Manchester Metropolitan University, to which I am most grateful.

Thanks to the staff at the Lyndon B. Johnson Library - in particular to John Wilson - who were very helpful and friendly, and made my trip to Austin, Texas, useful and enjoyable. Similarly, thanks to the staff at the Public Record Office in Kew who were equally efficient and helpful.

I should like to thank Mrs Stella Wood, Departmental Records Officer at the Department of Trade and Industry, for her assistance with the Board of Trade documents which at the time were classified. She kindly agreed to my request to see the documents covering the Kennedy Round so that I could research them. I am grateful to John Young for passing on relevant documents from the Dean Acheson 
Papers at the Truman Library, Independence, Missouri.

I am grateful also to the people who made important comments on the book: Betty Hanson, Martha Gibson, Garry Clifford, Geoff Berridge, Andrew Williams and Phil Deans. Thanks also to Kirsten Burke and Daryl Webb for help with wordprocessing.

I would like to record a personal thanks to several people. For encouragement and support in my early education I thank three excellent teachers: Dave Clayton, Dave Taylor and Jeff Taylor. My nineyear-old son Robert and seven-month-old daughter Katie didn't exactly help in the writing of this book. But their demands for attention sometimes brought a welcome distraction, and their delightful sense of humour often reminded me that life is such fun. The richest and most loving support came from my husband, Wayne Shannon. He read and commented on the many drafts of each chapter. His unceasing encouragement was the major factor in the completion of this work. Finally, this book is lovingly dedicated to my grandmother, Annetta Knowles, who helped make my early childhood so memorable and happy.

\section{NOTES}

1. A. Deighton, 'Say it with documents: British policy overseas, 1945-1952', Review of International Studies, 18 (1992) 393-402.

2. J. L. Gaddis, 'The expanding data base', International Security, 12 (1987) 3-21. Quoted in J. Melissen, 'Intra-alliance summitry: Macmillan, Kennedy and the road to Nassau, 18-20 December 1962', Diplomacy and Statecraft, 7 (1996) 652-87. See also R. H. Immerman, 'In search of history - and relevancy: breaking through the "Encrustations of Interpretation", Diplomatic History, 12 (1988) 341-56. For an excellent analysis of the problem of selection bias in the use of historical documents see I. S. Lustick, 'History, historiography, and political science: multiple historical records and the problem of selection bias', American Political Science Review, 90 (1996) 605-18.

3. This was the title of the now European Union in the $1960 \mathrm{~s}$ and to save confusion will be the one used throughout this book.

4. These were the papers of Francis Bator (Deputy Special Assistant to the President) and Henry Fowler (Under Secretary and Secretary of the Treasury). Relevant sections of the United Kingdom Country Files of the National Security Council were opened as recently as 1992.

5. See R. Aldrich, 'The Waldegrave Initiative and Secret Service archives: new materials and new policies', Intelligence and National Security, 10 (1995) 192-7. 



\section{List of Abbreviations}

ASP

CAP

CET

$\mathrm{ECSC}$

EEC

EFTA

GATT

IGA

NAFTA

NATO

STR

TEA

US

USTR

WEU
American Selling Price

Common Agricultural Policy

Common External Tariff

European Coal and Steel Community

European Economic Community

European Free Trade Association

General Agreement on Tariffs and Trade

International Grains Agreement

North American Free Trade Agreement

North Atlantic Treaty Organization

Special Trade Representative

Trade Expansion Act

United States

United States Trade Representative

Western European Union 